\title{
Safety and clinical outcomes of endoscopic ultrasound-guided gallbladder drainage with lumen-apposing metal stents in patients with dwell time over one year
}

\author{
Raúl Torres Yustea,b, Francisco Javier García-Alonsoa, Ramón Sánchez-Ocanaa, Marta Cimavillac, \\ Irene Peñas Herreroc, Ana Yaiza Carbajo a, Marina De Benito Sanza, Carlos De la Serna Higueraa, \\ Manuel Pérez-Miranda ${ }^{a}$
}

Hospital Universitario Río Hortega, Valladolid; Hospital General de Segovia; Hospital Río Carrión, Palencia, Spain

\begin{abstract}
Background Endoscopic ultrasound-guided gallbladder drainage (EUS-GBD) has proved effective in patients with cholecystitis at high surgical risk. The long-term risks of gallstone-related disease and stent-related adverse events are unknown.

Methods We performed a retrospective evaluation of a case series including subjects who underwent EUS-GBD using lumen-apposing metal stents (LAMS). Patients were identified from a prospective LAMS registry at a single tertiary center. Patients with a stent indwell time $<1$ year were excluded. Data regarding stent deployment and adverse events were retrieved from the prospective LAMS registry, while emergency room visits, admissions and causes of death were retrieved from electronic medical records.

Results We included 22 patients with a median age of 88.3 years (interquartile range [IQR]: 82.6-92.7), 14 (63.6\%) were male. Median follow up was 24.4 months (IQR: 18.2-42.4) and median time to the last available imaging procedure was 607 days (IQR: 463-938). No LAMS-related adverse events were identified beyond the first year of follow up. During follow up, 12 patients (54.5\%) visited the emergency room 34 times ( 1 visit/patient, IQR: $0-3)$ and a total of 36 hospital admissions were required, with a median of 1 admission/patient (IQR: 0-3). Fourteen (63.6\%) patients died during follow up. Only 1 patient (4.5\%) required new hospital admissions for gallstone-related disease.
\end{abstract}

Conclusions There were no adverse events beyond the first year after stent deployment, with only $4.5 \%$ of subjects requiring gallstone-related admissions. Permanent EUS-GBD with LAMS may be a definitive treatment for acute cholecystitis in patients ineligible for cholecystectomy.

Keywords Cholecystitis, drainage, endoscopy, digestive system, stents

Ann Gastroenterol 2019; 32 (5): 1-8

Gastroenterology Department, a Hospital Universitario Río Hortega, Valladolid (Raúl Torres Yuste, Francisco Javier García-Alonso, Ramón Sánchez-Ocana, Ana Yaiza Carbajo, Marina De Benito Sanz, Carlos De la Serna Higuera, Manuel Pérez-Miranda); ${ }^{b}$ Hospital General de Segovia, Segovia (Raúl Torres Yuste); 'Hospital Río Carrión, Palencia (Marta Cimavilla, Irene Peñas Herrero), Spain

Conflict of Interest: Raúl Torres Yuste, Javier García-Alonso, Ramón Sánchez-Ocana Hernández, Marta Cimavilla Román, Irene Peñas Herrero, Ana Yaiza Carbajo, Marina De Benito Sanz and Carlos De la Serna Higuera have no conflicts of interest or financial ties to disclose; Manuel Pérez-Miranda: Consultant: GI tech, BostonScientific, Gore. Speaker: Boston-Scientific, Olympus

Correspondence to: Raúl Torres Yuste, Calle Dulzaina 2, 47012

Valladolid, Spain, e-mail: tyraul89@gmail.com

Received 20 March 2019; accepted 27 May 2019; published online 20 June 2019

DOI: https://doi.org/10.20524/aog.2019.0395

\section{Introduction}

The first-line treatment for mild and moderate acute cholecystitis is early laparoscopic cholecystectomy [1]. In patients at high surgical risk, gallbladder drainage is a frequently chosen alternative [2], and percutaneous transhepatic gallbladder drainage (PTGBD) is the most commonly employed method. However, it has some drawbacks: it is uncomfortable and painful, drainage dislodgment takes place in up to $20 \%$ of patients [3], it is unsuitable for patients with coagulopathy or with massive ascites, and the rate of recurrence in patients who do not undergo cholecystectomy ranges between $22 \%$ and $47 \%$ [4].

Endoscopic transpapillary gallbladder drainage (ETGBD) and endoscopic ultrasonography-guided transmural gallbladder drainage (EUS-GBD) are promising alternative 
treatments for patients at high surgical risk. ETGBD solves $90 \%$ of cases of acute cholecystitis [5] and provides definitive drainage in patients unfit for surgery. Its main drawbacks are the technical difficulty of advancing a guidewire through the cystic duct, which accounts for the $<90 \%$ technical success described in some series [6], and the small caliber of the stents placed through the cystic duct, which are prone to obstruction. EUS-GBD is the most recent alternative to percutaneous cholecystostomy. A recent study showed that EUS-GBD and PTGBD have similar rates of technical (97\% vs. 97\%) and clinical (100\% vs. $96 \%$ ) success, without a significant difference in complication rates (7\% vs. 3\%) [7].

The first stents used for EUS-GBD were self-expandable metal stents (SEMS), initially designed for intraluminal deployment. Therefore, they might be more prone to bile leakage and migration, as they do not provide lumen anchorage. Lumen-apposing metal stents (LAMS) were specifically designed to anchor to hollow viscera, solving the limitations of conventional SEMS in this setting [8], although concerns about adverse events have been raised. A recent cautionary report of an ongoing trial (NCT02685865) evaluating endoscopic drainage of walled-off necrosis [9] described significant delayed adverse events in 6 patients after LAMS were deployed in 12. On the other hand, studies evaluating EUS-GBD have not shown such high rates of adverse events $[10,11]$ and longterm stent indwelling might reduce the risk of recurrence [4], but data beyond the year of follow up are still scarce. Thus, the convenience of leaving the LAMS in situ in EUS-GBD performed in non-surgical candidates is still a matter of debate.

Our study aimed to analyze the long-term ( $>1$ year) outcomes of subjects who underwent EUS-GBD employing a LAMS, including new biliary events, hospital admissions, and all-cause mortality.

\section{Patients and methods}

The present study was a single-center retrospective case series evaluating the long-term outcomes of patients who underwent EUS-GBD for acute cholecystitis. It was approved by the local institutional review board (IRB). All authors had access to the study data and have reviewed and approved the final manuscript.

\section{Selection of patients}

Patients were prospectively enrolled in an IRB-approved LAMS registry, including all LAMS deployed in a single academic tertiary care center. All patients or their legal representatives provided written informed consent. Those who underwent EUS-GBD for acute cholecystitis between May 2011 and November 2015 were eligible to participate in this study. Patients with an indwell time $<12$ months were excluded. Short-term outcomes of some of these patients have been reported previously [10-13].

\section{Procedure}

All procedures were performed by 2 expert endoscopists (MPM, CdlSH) in the endoscopy suite. All patients were sedated by intravenous administration of midazolam and propofol. The gallbladder was imaged under EUS from the antrum or the duodenal bulb with a therapeutic echoendoscope [14] and then punctured with a 19-G needle (Expect; Boston Scientific), avoiding intervening vessels. After that, a 0.035-inch guidewire (Hydra Jagwire; Boston Scientific) was passed through the needle and coiled in the gallbladder. The LAMS (AXIOS, Boston Scientific) deployment technique depended on the type of stent chosen. If a conventional LAMS (AXIOS, Boston Scientific) was chosen, serial dilatation with 6-Fr cystotome (Cysto-Gastro-Set, Endo-flex) followed by a 4-mm biliary balloon (Hurricane, Boston Scientific) was performed prior to the insertion of the stent under EUS and fluoroscopic guidance. In case of an electrocautery-enhanced (hot) LAMS (AXIOS, Boston Scientific) the stent was deployed directly over the guidewire. Hot LAMS also permits a freehand technique, whereby direct access to the target is achieved without prior needle puncture. The LAMS used were 10 or $15 \mathrm{~mm}$ in diameter. Coaxial double-pigtail plastic stent (Boston Scientific) insertion and dilation within the stent lumen with a 10- or 15-mm balloon dilator (Controlled Radial Expansion balloon dilator; Boston Scientific) to achieve rapid deployment and prevent potential dislodgement secondary to therapeutic maneuvers through it were performed at the discretion of the endoscopist.

\section{Definitions}

Acute cholecystitis was diagnosed according to the Tokyo guidelines criteria, based on a combination of clinical symptoms (fever, right upper quadrant pain, positive Murphy's sign), laboratory data (high level of serum C-reactive protein, leukocytosis) and imaging findings (US, EUS or CT) [15]. Cholecystectomy was dismissed in all cases because of the patients' advanced age and poor physical status (class $\geq$ III on the American Society of Anesthesiologists' Physical Status classification). None of the patients improved after 24-72 h of conservative management with intravenous antibiotics, fluid replacement and bowel rest.

Complications were defined as any procedure-related event appearing during or after the procedure; they were described according to their nature and graded for severity according to the American Society for Gastrointestinal Endoscopy lexicon's severity grading system [16].

Causes of admission during follow up were categorized according to the diagnoses stated in the discharge reports, codified according to the International Classification of Disease 9-Clinical Modification (ICD9-CM). End of follow up was defined as the occurrence of death, relapse, discharge from the outpatient clinic, or, in the absence of any of these, the last outpatient clinic medical visit or the last telephone follow up. 


\section{Aim}

To assess the long-term clinical outcomes of EUS-GBD with LAMS in definitive non-operative candidates.

\section{Data retrieval}

Data regarding baseline demographics and diagnosis, endoscopic procedure, adverse events, migration, stent retrieval, and mortality were retrieved from the prospective LAMS registry available in our center. Fifteen patients were followed in our institution. The remaining 7 patients belong to another 4 institutions. In addition, all-cause emergency room visits and hospital admissions were retrieved from medical electronic records, which included all notes made by physicians on outpatient visits, as well as reports of analysis, cultures, imaging studies, and all other procedures performed. Discharge reports after every hospital admission were also included. All patients were contacted by phone to ensure that no procedures or admissions at other centers were missed. Patients' data were collected into a newly created database. In case of unclear or contradictory statements in the medical record, a consensus decision was made.

\section{Statistical analysis}

The analysis was performed with Stata (StataCorp. 2013. College Station, TX). Categorical variables were represented as percentages. Continuous variables with a normal distribution were presented as mean and standard deviation and those without a normal distribution were summarized as median and interquartile range (IQR).

\section{Results}

A total of 47 patients with EUS-GBD employing a LAMS were identified. Twenty-five of them were excluded for having an indwell time under 12 months, as shown in Fig. 1. Stent dysfunction included 1 partial gastric outlet obstruction and an angulated stent resulting in relapse of cholecystitis. One of the 12 deaths presenting in the first year of follow up was related to the procedure (hemoperitoneum). Thus, 22 patients were included in the final analysis: $14(63.6 \%)$ male and $8(36.4 \%)$ female with a median age of 88.3 years (IQR: 82.6-92.7; range 71.3-97.5). Fourteen $(63.6 \%)$ patients had undergone ERCP, 11 of them in the same procedure as when the LAMS was deployed.

\section{Procedure description}

All procedures are summarized in Table 1. Transgastric access was chosen in $15 / 22$ patients while coaxial stents were placed in only $3 / 22$ subjects.

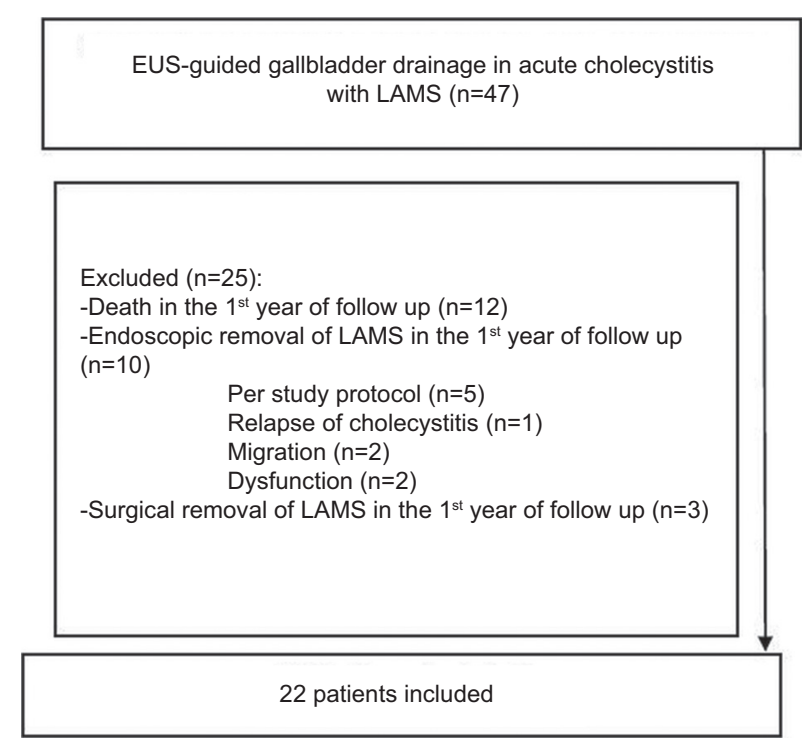

Figure 1 Flowchart showing patient selection

EUS, endoscopic ultrasound; LAMS, lumen-apposing metal stent

Table 1 Deployment intervention

\begin{tabular}{lc}
\hline Parameter & Value \\
\hline $\begin{array}{l}\text { Access route, } \mathrm{n}(\%) \\
\text { Transgastric }\end{array}$ & $15(68.2 \%)$ \\
$\quad$ Transduodenal & $7(31.8 \%)$ \\
Type of lumen-apposing metal stent, $\mathrm{n}(\%)$ & \\
$\quad$ Conventional (cold) & $15(68.2 \%)$ \\
$\quad$ Electrocautery enhanced (hot) & $7(31.8 \%)$ \\
\hline Stent dimensions, $\mathrm{n}(\%)$ & $15(68.2 \%)$ \\
$10 \times 15$ mm & $7(31.8 \%)$ \\
$\quad 10 \times 10$ mm & $3(13.6 \%)$ \\
Placement of coaxial stents, $\mathrm{n}(\%)$ & $2(9.1 \%)$ \\
Double pigtail plastic stent & $1(4.5 \%)$ \\
Double pigtail plastic stent and self-expandable & \\
metal stent & $3(13.6 \%)$ \\
Stent balloon dilation, $\mathrm{n}(\%)$ & $8(36.4 \%)$ \\
\hline Cholecystoscopy and stone extraction, $\mathrm{n}(\%)$ & \\
\hline
\end{tabular}

\section{Follow up}

Median follow up was 24.4 months (IQR: 18.2-42.4; range 12.3-62.4). All emergency room visits, hospital admissions and causes of death are summarized in Table 2. During long-term follow up, 12 patients (54.5\%) visited the emergency room 34 times with a median of 1 visit/patient (IQR: 0-3; range 0-7). A total of 36 hospital admissions were required, with a median of 1 admission/patient (IQR: 0-3; range 0-9). Among the 22 patients included, 14 (63.6\%) patients died during follow up: one of them of pancreatic cancer progression, while the rest died from non-biliary causes.

In 15 patients (68\%), imaging at least 3 months after deployment was available, confirming the presence of the LAMS in $100 \%$. In the remaining 7 patients there was no image available 
4 R. T. Yuste et al

Table 2 Causes of death, hospital admissions and emergency room visits

\begin{tabular}{|c|c|c|c|c|c|c|}
\hline Patient & Sex & $\begin{array}{l}\text { Age at } \\
\text { deployment } \\
\text { (years) }\end{array}$ & $\begin{array}{l}\text { High surgical } \\
\text { risk factors }\end{array}$ & $\begin{array}{l}\text { Emergency room } \\
\text { visits } \\
\text { (months after } \\
\text { deployment) }\end{array}$ & $\begin{array}{l}\text { Admissions } \\
\text { (months after deployment) }\end{array}$ & $\begin{array}{l}\text { Cause of death } \\
\text { (months after } \\
\text { deployment) }\end{array}$ \\
\hline 1 & Male & 84 & $\begin{array}{l}\text { Elderly } \\
\text { Congestive } \\
\text { heart failure }\end{array}$ & $\begin{array}{l}\text { Diarrhea (14) } \\
\text { Acute pain due to } \\
\text { trauma (35) } \\
\text { Congestive heart } \\
\text { failure (52) }\end{array}$ & None & None \\
\hline 2 & Male & 93 & $\begin{array}{l}\text { Elderly } \\
\text { Congestive } \\
\text { heart failure }\end{array}$ & None & None & $\begin{array}{l}\text { Congestive heart } \\
\text { failure (24) }\end{array}$ \\
\hline 3 & Male & 73 & Severe COPD & $\begin{array}{l}\text { Hypertensive } \\
\text { emergency (40) }\end{array}$ & COPD (15) & None \\
\hline 4 & Male & 85 & Severe COPD & None & None & COPD (24) \\
\hline 5 & Male & 85 & $\begin{array}{l}\text { Elderly } \\
\text { Cardiovascular } \\
\text { risk factors }\end{array}$ & None & $\begin{array}{l}\text { Malignant neoplasm of colon (acute } \\
\text { obstruction) (47) }\end{array}$ & $\begin{array}{l}\text { Malignant neoplasm } \\
\text { of colon }(47)\end{array}$ \\
\hline 6 & Male & 90 & $\begin{array}{l}\text { Elderly } \\
\text { Cardiovascular } \\
\text { risk factors }\end{array}$ & $\begin{array}{l}\text { Syncope (5) } \\
\text { Skin lesions (2 times) } \\
(7,8) \\
\text { Urinary tract } \\
\text { infection (12) } \\
\text { Hematuria (2 times) } \\
(16,18)\end{array}$ & $\begin{array}{l}\text { Pneumonia (10) } \\
\text { Urinary sepsis (13) } \\
\text { Peptic esophagitis (20) } \\
\text { Cutaneous ulcer infection (24) }\end{array}$ & $\begin{array}{l}\text { Cutaneous } \\
\text { sepsis (24) }\end{array}$ \\
\hline 7 & Male & 96 & $\begin{array}{l}\text { Elderly } \\
\text { Congestive } \\
\text { heart failure }\end{array}$ & None & None & $\begin{array}{l}\text { Congestive heart } \\
\text { failure (18) }\end{array}$ \\
\hline 8 & Female & 82 & $\begin{array}{l}\text { Elderly } \\
\text { Cardiovascular } \\
\text { risk factors }\end{array}$ & $\begin{array}{l}\text { Urinary tract } \\
\text { infection }(4 \text { times }) \\
(3,4,8,11) \\
\text { Acute pain due to } \\
\text { trauma } \\
(2 \text { times })(4,5) \\
\text { Hypertensive } \\
\text { emergency }(8)\end{array}$ & $\begin{array}{l}\text { Sepsis (10) } \\
\text { Atrial fibrillation (12) } \\
\text { Cutaneous sepsis (15) }\end{array}$ & $\begin{array}{l}\text { Cutaneous } \\
\text { sepsis (15) }\end{array}$ \\
\hline 9 & Male & 89 & $\begin{array}{l}\text { Elderly } \\
\text { Cardiovascular } \\
\text { risk factors }\end{array}$ & $\begin{array}{l}\text { Acute pain due to } \\
\text { trauma } \\
(4 \text { times })(15,16 \\
30,30)\end{array}$ & Urinary tract infection (40) & None \\
\hline 10 & Female & 84 & $\begin{array}{l}\text { Elderly } \\
\text { Cardiovascular } \\
\text { risk factors }\end{array}$ & $\begin{array}{l}\text { Back pain (3 times) } \\
(2,3,10)\end{array}$ & $\begin{array}{l}\text { Urinary tract infection ( } 2 \text { times) } \\
(6,28) \\
\text { Acute coronary syndrome }(25)\end{array}$ & Stroke (44) \\
\hline 11 & Male & 88 & $\begin{array}{l}\text { Elderly } \\
\text { Cardiovascular } \\
\text { risk factors }\end{array}$ & $\begin{array}{l}\text { Transient ischemic } \\
\text { attack (23) }\end{array}$ & Hip fracture (7) & None \\
\hline 12 & Female & 78 & Malignancy & $\begin{array}{l}\text { Deep venous } \\
\text { thrombosis }(5) \\
\text { Anemia }(2 \text { times }) \\
(23,25) \\
\text { Metrorrhagia (8) }\end{array}$ & $\begin{array}{l}\text { Cholangitis (13) } \\
\text { Upper gastrointestinal } \\
\text { bleeding/anemia due to portal } \\
\text { hypertension ( } 5 \text { times) }(19,24,25 \text {, } \\
29,31) \\
\text { Sepsis of unknown origin (20) } \\
\text { Pneumonia (21) } \\
\text { Biliary obstruction (27) }\end{array}$ & $\begin{array}{l}\text { Pancreatic } \\
\text { adenocarcinoma (33) }\end{array}$ \\
\hline
\end{tabular}

(Contd...) 
Table 2 (Continued)

\begin{tabular}{|c|c|c|c|c|c|c|}
\hline Patient & Sex & $\begin{array}{l}\text { Age at } \\
\text { deployment } \\
\text { (years) }\end{array}$ & $\begin{array}{l}\text { High surgical } \\
\text { risk factors }\end{array}$ & $\begin{array}{l}\text { Emergency room } \\
\text { visits } \\
\text { (months after } \\
\text { deployment) }\end{array}$ & $\begin{array}{l}\text { Admissions } \\
\text { (months after deployment) }\end{array}$ & $\begin{array}{l}\text { Cause of death } \\
\text { (months after } \\
\text { deployment) }\end{array}$ \\
\hline 13 & Male & 87 & $\begin{array}{l}\text { Elderly } \\
\text { Cardiovascular } \\
\text { risk factors }\end{array}$ & Pneumonia (6) & None & Pneumonia (16) \\
\hline 14 & Male & 71 & Malignancy & Epistaxis (18) & $\begin{array}{l}\text { Pneumonia/bronchitis ( } 4 \text { times) }(3, \\
11,14,20) \\
\text { Respiratory failure (lung } \\
\text { cancer) }(2 \text { times })(21,23)\end{array}$ & Lung cancer (23) \\
\hline 15 & Male & 91 & $\begin{array}{l}\text { Elderly } \\
\text { Cardiovascular } \\
\text { risk factors }\end{array}$ & None & Stroke (25) & Stroke (25) \\
\hline 16 & Male & 82 & $\begin{array}{l}\text { Elderly } \\
\text { Cardiovascular } \\
\text { risk factors }\end{array}$ & Diarrhea (10) & $\begin{array}{l}\text { Diarrhea (11) } \\
\text { Stroke (20) }\end{array}$ & Stroke (20) \\
\hline 17 & Female & 92 & $\begin{array}{l}\text { Elderly } \\
\text { Cardiovascular } \\
\text { risk factors }\end{array}$ & None & $\begin{array}{l}\text { Choledocholithiasis+cholangitis } \\
(2 \text { times })(8,15) \\
\text { Urinary tract infection }(11) \\
\text { Hip fracture }(18)\end{array}$ & None \\
\hline 18 & Female & 95 & $\begin{array}{l}\text { Elderly } \\
\text { Cardiovascular } \\
\text { risk factors }\end{array}$ & None & None & Stroke (20) \\
\hline 19 & Female & 97 & $\begin{array}{l}\text { Elderly } \\
\text { Congestive } \\
\text { heart failure }\end{array}$ & None & None & $\begin{array}{l}\text { Congestive heart } \\
\text { failure (20) }\end{array}$ \\
\hline 20 & Female & 92 & $\begin{array}{l}\text { Elderly } \\
\text { Cardiovascular } \\
\text { risk factors }\end{array}$ & Pneumonia (5) & None & None \\
\hline 21 & Male & 90 & $\begin{array}{l}\text { Elderly } \\
\text { Cardiovascular } \\
\text { risk factors }\end{array}$ & None & None & None \\
\hline 22 & Female & 97 & $\begin{array}{l}\text { Elderly } \\
\text { Cardiovascular } \\
\text { risk factors }\end{array}$ & None & None & None \\
\hline
\end{tabular}

COPD, chronic obstructive pulmonary disease; $n / a$, not available

from at least 3 months after deployment. Median time from LAMS deployment to the last available imaging procedure was 607 days (IQR: 463-938; range 186-1566). Fig. 2A and B present in situ LAMS in CT scans performed during hospital admissions.

Long-term endoscopic follow up was available in 3 patients. One patient with a cholecystoduodenostomy was evaluated 31 months after deployment and found to have a patent stent (Fig. 3A). One patient with a cholecystogastrostomy, in an esophagogastroduodenoscopy performed 42 months after the deployment, exhibited a significant overgrowth in the LAMS causing obstruction of the stent (Fig. 3B). Another patient with a cholecystogastrostomy showed a patent fistula in the last endoscopic follow up, but not the stent (Fig. 4A). An abdominal plain film (Fig. 4B) confirmed the suspected buried-stent syndrome, confirming the presence of the LAMS in the right upper quadrant. Table 3 displays data regarding migration and patency evaluation.

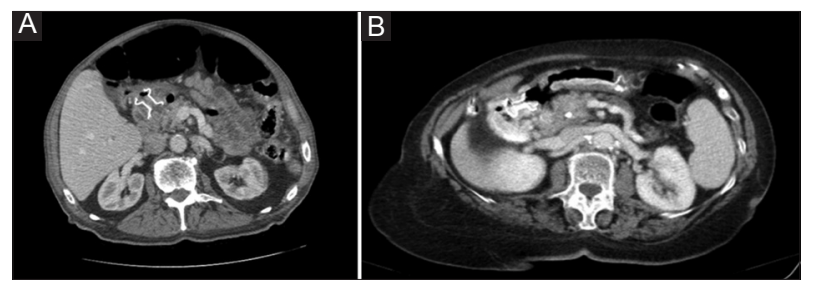

Figure 2 (A) Computed tomography (CT) scan performed for obstructive colonic cancer showing a lumen-apposing metal stent (LAMS) with an indwell time of 4 years. (B) CT scan of a patient with a LAMS indwell time of 27 months

\section{Biliary and gastrointestinal events during follow up}

Two of the 22 patients (9\%) required new hospital admissions for biliary disease, but just 1 for gallstone-related disease (4.5\%): a patient presenting 2 episodes of moderately 
Table 3 Radiologic and endoscopic data assessing migration and patency

\begin{tabular}{|c|c|c|c|}
\hline Patient & Last imaging & $\begin{array}{l}\text { Months after LAMS } \\
\text { deployment of last imaging }\end{array}$ & $\begin{array}{l}\text { Esophagogastroduodenoscopy: months } \\
\text { after deployment and patency status }\end{array}$ \\
\hline 1 & Abdominal X-ray & 51 & 61 (buried but patent fistula) \\
\hline 2 & Ultrasonography & 6 & $\mathrm{n} / \mathrm{a}$ \\
\hline 3 & Abdominal X-ray & 20 & $\mathrm{n} / \mathrm{a}$ \\
\hline 4 & $\mathrm{n} / \mathrm{a}$ & $\mathrm{n} / \mathrm{a}$ & $\mathrm{n} / \mathrm{a}$ \\
\hline 5 & Abdominal CT & 47 & $\mathrm{n} / \mathrm{a}$ \\
\hline 6 & Abdominal X-ray & 19 & $\mathrm{n} / \mathrm{a}$ \\
\hline 7 & $\mathrm{n} / \mathrm{a}$ & $\mathrm{n} / \mathrm{a}$ & $\mathrm{n} / \mathrm{a}$ \\
\hline 8 & Abdominal X-ray & 15 & $\mathrm{n} / \mathrm{a}$ \\
\hline 9 & Abdominal X-ray & $\mathrm{n} / \mathrm{a}$ & $\mathrm{n} / \mathrm{a}$ \\
\hline 10 & Ultrasonography & 43 & 42 (overgrowth) \\
\hline 11 & Abdominal X-ray & 39 & $\mathrm{n} / \mathrm{a}$ \\
\hline 12 & Ultrasonography & 30 & 31 (patent stent) \\
\hline 13 & Abdominal X-ray & 15 & $\mathrm{n} / \mathrm{a}$ \\
\hline 14 & Abdominal X-ray & 13 & $\mathrm{n} / \mathrm{a}$ \\
\hline 15 & Abdominal X-ray & 13 & $\mathrm{n} / \mathrm{a}$ \\
\hline 16 & Abdominal X-ray & 19 & $\mathrm{n} / \mathrm{a}$ \\
\hline 17 & Abdominal X-ray & 23 & $\mathrm{n} / \mathrm{a}$ \\
\hline 18 & Abdominal X-ray & $\mathrm{n} / \mathrm{a}$ & $\mathrm{n} / \mathrm{a}$ \\
\hline 19 & Abdominal X-ray & 19 & $\mathrm{n} / \mathrm{a}$ \\
\hline 20 & $\mathrm{n} / \mathrm{a}$ & $\mathrm{n} / \mathrm{a}$ & $\mathrm{n} / \mathrm{a}$ \\
\hline 21 & $\mathrm{n} / \mathrm{a}$ & $\mathrm{n} / \mathrm{a}$ & $\mathrm{n} / \mathrm{a}$ \\
\hline 22 & $\mathrm{n} / \mathrm{a}$ & $\mathrm{n} / \mathrm{a}$ & $\mathrm{n} / \mathrm{a}$ \\
\hline
\end{tabular}

CT, computed tomography; LAMS, lumen-apposing metal stent; $n / a$, not available
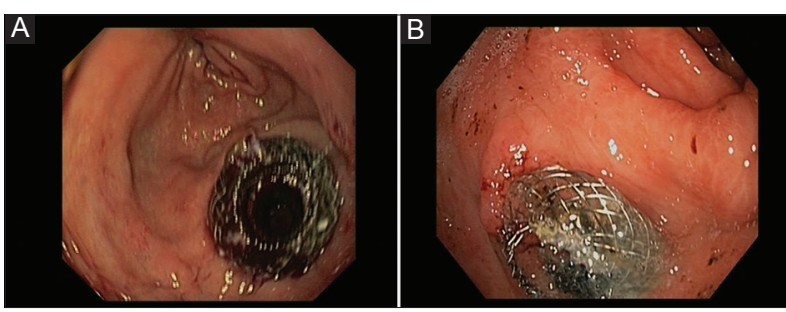

Figure 3 (A) Patent cholecystoduodenostomy employing a $10 \times 10 \mathrm{~mm}$ lumen-apposing metal stent (LAMS) 31 months after deployment. (B) Cholecystogastrostomy showing overgrowth 42 months after LAMS deployment

acute cholangitis with choledocholithiasis. The other presented obstructive jaundice and moderately acute cholangitis related to pancreatic malignancy. Neither recurrences of cholecystitis nor cases of gastric outlet obstruction or gallbladder sump syndrome were observed during follow up.

Six episodes of upper gastrointestinal bleeding were diagnosed in 2 patients, none of them related to the LAMS. One patient presented peptic erosive esophagitis and the other presented 5 episodes of acute variceal bleeding and portal hypertensive gastropathy.

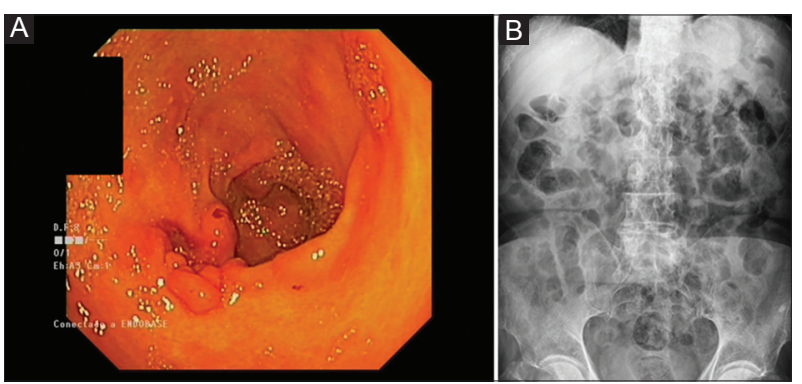

Figure 4 Cholecystogastrostomy with a $15 \times 10 \mathrm{~mm}$ lumen-apposing metal stent 61.5 months after deployment, showing a patent fistula with a completely buried stent (A), confirmed by its presence on the abdominal X-ray film (B)

\section{Discussion}

Our study presents the first cohort published to date analyzing long-term outcomes of EUS-GBD with indwelling LAMS. Patients with an indwell time $\geq 12$ months were identified from a prospective LAMS registry that included baseline demographics and endoscopic procedure data. Follow up was documented with medical records, endoscopy, imaging and phone contact. 
It is important to highlight the complexity of the management of this specific population. This is shown by the fact that $25.5 \%$ of the initial cohort died before completing the first year of follow up. The difficulty of the procedure, even in expert hands also poses a risk of dysfunction, migration or even surgery. Nevertheless, acute cholecystitis presents a high mortality in this group of patients [3] and EUS-GBD aims to both control the acute infection and reduce the risk of relapse in a single procedure.

Focusing on our cohort, we observed a relevant effect on the number of gallstone-related admissions, with only one patient (4.5\%) requiring 2 admissions for acute cholangitis during a median follow up of 24.4 months. Although our cohort was small, this proportion is similar to the $4 \%$ readmission rates identified in patients undergoing cholecystectomy in large retrospective studies with a follow up of 2 years [17]. Our findings also resemble those shown in the largest study published to date, by Choi et al, which included 56 patients with a shorter follow up (median 275 days, range 40-1185), presenting recurrent acute cholecystitis in 2 patients (3.6\%) [4]. It should be taken into account that patients with cholecystitis who do not undergo cholecystectomy present rates of readmission for gallstone-related disease of $38 \%$ in the subsequent 2 years [17].

Adverse events are a significant concern in the long-term deployment of LAMS. Currently available evidence is drawn mainly from studies evaluating the management of pancreatic fluid collections. A recently published report of an ongoing trial (NCT02685865) that evaluated LAMS for walled-off necrosis drainage reported severe delayed gastrointestinal bleeding in 3 patients, buried LAMS syndrome in 2 patients and biliary stricture in 1 of the 12 patients included [9], but previous published series and ongoing registries have shown significantly lower rates of adverse events, ranging from 5-15\% [18-21]. The possibility of extrapolating these results to EUS-GBD is yet to be determined, as pancreatic fluid collections are pathological cavities with an inflammatory cause and their size collapses after treatment. No LAMS-related adverse events were observed in our cohort of patients after the first year of follow up, although there were early adverse events, including 2 cases of stent migration, 2 of stent dysfunction and 1 fatal bleeding. The study by Choi et al identified no adverse events beyond the first year [4]. A multicenter retrospective study by Walter et al, which included 15 patients whose EUS-GBD was left in situ with a mean follow up of 364 days (standard deviation: 67 days) [11], reported 4 procedure-related adverse events (13\%), although the time to adverse events was not reported. We hypothesize that late migration and gastrointestinal bleeding are infrequent because of tissue overgrowth.

This study has significant limitations which should not be overlooked. Firstly, its retrospective design might have underestimated the number of adverse events. We tried to correct for this with a thorough search of medical records and phone contact with patients or their relatives. Secondly, longterm endoscopic or imaging studies were not available in all patients and the imaging follow up was shorter than the clinical one. Thus, the number of migrations might be underestimated. Nonetheless, migration of LAMS after EUS-GBD seems to be frequently symptomatic (all identified migrations in our cohort were symptomatic), although in a study by Choi et al there were 2 asymptomatic migrations [4] in the first year after deployment. Thirdly, the single-center design of the study, with all procedures performed by 2 expert endoscopists, might not allow the extrapolation of results to other centers where endoscopists may have varying levels of expertise in EUS-GBD or limited experience in the use of LAMS.

In summary, our study shows that long term indwell of EUSGBD with LAMS provides a definitive drainage of the gallbladder, reducing the risk of further biliary events. Moreover, leaving the LAMS in place avoided a further invasive procedure in elderly patients with high surgical risk. We observed no delayed LAMSrelated adverse events after a thorough assessment of all-cause emergency room visits, admissions and mortality. Thus, we suggest permanent EUS-GBD should be considered in patients with high surgical risk who present with moderate/severe acute cholecystitis, although large comparative studies are needed to confirm these promising results.

\section{Summary Box}

\section{What is already known:}

- The first-line treatment for acute cholecystitis is laparoscopic cholecystectomy

- Endoscopic ultrasound-guided gallbladder drainage, when performed by skilled endoscopists, is an effective alternative treatment for acute cholecystitis in patients unfit for surgery

- Long-term results beyond 1 year of follow up are still scarce

\section{What the new findings are:}

- Long-term indwell of endoscopic ultrasoundguided gallbladder drainage using lumen-apposing metal stents (LAMS) reduces the risk of further biliary events in patients who do not undergo cholecystectomy

- No delayed LAMS-related adverse events were identified after a median follow up of over 2 years

\section{References}

1. Yamashita Y, Takada T, Strasberg SM, et al; Tokyo Guideline Revision Committee. TG13 surgical management of acute cholecystitis. J Hepatobiliary Pancreat Sci 2013;20:89-96.

2. Tsuyuguchi T, Itoi T, Takada T, et al; Tokyo Guideline Revision Committee. TG13 indications and techniques for gallbladder drainage in acute cholecystitis (with videos). J Hepatobiliary Pancreat Sci 2013;20:81-88.

3. García-Alonso FJ, de Lucas Gallego, Bonillo Cambrodón D, et al. Gallstone-related disease in the elderly: is there room for improvement? Dig Dis Sci 2015;60:1770-1777. 
4. Choi JH, Lee SS, Choi JH, et al. Long-term outcomes after endoscopic ultrasonography-guided gallbladder drainage for acute cholecystitis. Endoscopy 2014;46:656-661.

5. Baron TH, Grimm IS, Swanstrom LL. Interventional approaches to gallbladder disease. N Engl J Med 2015;373:357-365.

6. Itoi $\mathrm{T}$, Sofuni A, Itokawa $\mathrm{F}$, et al. Endoscopic transpapillary gallbladder drainage in patients with acute cholecystitis in whom percutaneous transhepatic approach is contraindicated or anatomically impossible (with video). Gastrointest Endosc 2008;68:455-460.

7. Jang JW, Lee SS, Song TJ, et al. Endoscopic ultrasound-guided transmural and percutaneous transhepatic gallbladder drainage are comparable for acute cholecystitis. Gastroenterology 2012;142:805-811.

8. Binmoeller KF, Shah J. A novel lumen-apposing stent for transluminal drainage of nonadherent extraintestinal fluid collections. Endoscopy 2011;43:337-342.

9. Bang JY, Hasan M, Navaneethan U, Hawes R, Varadarajulu S. Lumen-apposing metal stents (LAMS) for pancreatic fluid collection (PFC) drainage: may not be business as usual. Gut 2017;66:2054-2056.

10. de la Serna-Higuera C, Pérez-Miranda M, Gil-Simón P, et al. EUS-guided transenteric gallbladder drainage with a new fistulaforming, lumen-apposing metal stent. Gastrointest Endosc 2013;77:303-308.

11. Walter D, Teoh AY, Itoi T, et al. EUS-guided gall bladder drainage with a lumen-apposing metal stent: a prospective long-term evaluation. Gut 2016;65:6-8.

12. Teoh AYB, Serna C, Penas I, et al. Endoscopic ultrasoundguided gallbladder drainage reduces adverse events compared with percutaneous cholecystostomy in patients who are unfit for cholecystectomy. Endoscopy 2017;49:130-138.

13. Kahaleh M, Perez-Miranda M, Artifon EL, et al. International collaborative study on EUS-guided gallbladder drainage: Are we ready for prime time? Dig Liver Dis 2016;48:1054-1057.

14. Peñas-Herrero I, de la Serna-Higuera C, Perez-Miranda M. Endoscopic ultrasound-guided gallbladder drainage for the management of acute cholecystitis (with video). J Hepatobiliary Pancreat Sci 2015;22:35-43.

15. Yokoe M, Takada T, Strasberg SM, et al; Tokyo Guidelines Revision Committee. TG13 diagnostic criteria and severity grading of acute cholecystitis (with videos). J Hepatobiliary Pancreat Sci 2013;20:35-46.

16. Cotton PB, Eisen GM, Aabakken L, et al. A lexicon for endoscopic adverse events: report of an ASGE workshop. Gastrointest Endosc 2010;71:446-454.

17. Riall TS, Zhang D, Townsend CM Jr, Kuo YF, Goodwin JS. Failure to perform cholecystectomy for acute cholecystitis in elderly patients is associated with increased morbidity, mortality, and cost. J Am Coll Surg 2010;210:668-677, 677-679.

18. Ryan BM, Venkatachalapathy SV, Huggett MT; UK and Ireland Hot AXIOS Study Group. Safety of lumen-apposing metal stents (LAMS) for pancreatic fluid collection drainage. Gut 2017;66:1530-1531.

19. Lakhtakia S, Basha J, Talukdar R, et al. Endoscopic "step-up approach" using a dedicated biflanged metal stent reduces the need for direct necrosectomy in walled-off necrosis (with videos). Gastrointest Endosc 2017;85:1243-1252.

20. Rinninella E, Kunda R, Dollhopf M, et al. EUS-guided drainage of pancreatic fluid collections using a novel lumen-apposing metal stent on an electrocautery-enhanced delivery system: a large retrospective study (with video). Gastrointest Endosc 2015;82:1039-1046.

21. Sharaiha RZ, Tyberg A, Khashab MA, et al. Endoscopic therapy with lumen-apposing metal stents is safe and effective for patients with pancreatic walled-off necrosis. Clin Gastroenterol Hepatol 2016;14:1797-1803. 